\title{
Sequestration of Pb(II) from Aqueous Environment by Palm Kernel Shell Activated Carbon: Isotherm and Kinetic Analyses
}

\author{
Ekemini Monday Isokise ${ }^{1}$, Abdul Halim Abdullah ${ }^{1,2 *}$ and Tan Yen Ping ${ }^{2}$ \\ ${ }^{1}$ Material Synthesis and Characterization Laboratory, Institute of Advanced Technology, Universiti Putra \\ Malaysia, 43400 UPM, Serdang, Selangor Darul Ehsan, Malaysia \\ ${ }^{2}$ Department of Chemistry, Faculty of Science, Universiti Putra Malaysia, 43400 UPM, Serdang, Selangor \\ Darul Ehsan, Malaysia
}

\begin{abstract}
In this work, activated carbons were produced by the thermochemical treatment of palm kernel shells with different activation time. The developed products (activated carbon samples) were described by their surface area, porosity, and applied for lead(II) ions separation from liquid phase. By prolonging the activation time beyond $2 \mathrm{~h}$, some of the micropores collapsed to form mesopores without causing a significant transformation in the surface area. The influences of solution $\mathrm{pH}$, mass of biosorbents, concentration of $\mathrm{Pb}$ (II) ions, and temperature on the entrapment of lead(II) ions explored. Based on experimental outcome, the best-suited condition for the $\mathrm{Pb}$ (II) uptake was $0.13 \mathrm{~g} \mathrm{AC}-4,250 \mathrm{mg} \mathrm{L}^{-1}$ concentration,

ARTICLE INFO

Article history:

Received: 4 January 2021

Accepted: 19 April 2021

Published: 19 July 2021

DOI: https://doi.org/10.47836/pjst.29.3.17

E-mail addresses:

kemsguy@gmail.com (Ekemini Monday Isokise)

halim@upm.edu.my (Abdul Halim Abdullah)

typ@upm.edu.my (Tan Yen Ping)

*Corresponding author and $\mathrm{pH}$. The $\mathrm{Pb}(\mathrm{II})$ entrapment process is thermodynamically exothermic and spontaneous. The adsorption data fit the Langmuir monolayer adsorption model, with $222 \mathrm{mg} \mathrm{g}^{-1}$ as maximum sorption capacity, and the Ho-second-order kinetics model suitably described the process rate.

Keywords: Activated carbon, adsorption, heavy metals, isotherm, palm kernel shell
\end{abstract}




\section{INTRODUCTION}

Presence of heavy metal ions, especially lead in water bodies constitute environmental pollution because they are not biodegradable and highly poisonous to human and aquatic organisms. The discharge of industrial effluent without apposite treatment, jeopardize the environment and consequently public health (Krika et al., 2016). Lead extrudes into the environment through mining and smelting, paint and rubber industries, and battery manufacturing, recycling, and disposal. Content of lead in industrial effluent varied from one industrial activity to another, while the regulated contamination level is $0 \mathrm{ppm}$, according to the United States Environmental Protection Agency (EPA, 2017). Several separation techniques, including electrocoagulation, chemical oxidation and precipitation, ion-exchange, and membrane filtration, are available for separating heavy metal ions from liquid phase.

The methods highlighted above are not without shortcomings. For instance, chemical precipitation and coagulation methods are straightforward to operate and inexpensive, but excessive sludge is generated, leading to disposal problem. The ion-exchange treatment progression is non-selective and highly depend on $\mathrm{pH}$ (Malik et al., 2016). Adsorption is the favourable and commonly adopted technique for the sequestration of heavy metals ions because of its eco-friendliness and simple procedure, produce limited secondary environmental pollution, and capable of removing low concentration heavy metal ions (Zuo, 2014; Tang et al., 2017). Among various solid adsorbents employed, activated carbon is a widely used due to its larger surface area and porosity. The use of agricultural and industrial wastes as starting ingredients in the manufacture of activated carbon has gained interest because of the high expenses associated with commercial activated carbon, coal, and lignite.

One of the major exporters of products from palm oil is Malaysia. The associated waste products generated from the industrial milling operation of the palm oil produce such as trunks, mesocarp fiber, empty fruit bunches, fronds, and its shells (Poudel et al., 2017; Sani et al., 2015). Approximately $60 \%$ of the resulted fibers and shells are employed as fuel for electricity and steam generation, out of the industrial wastes (Shafie et al., 2012). This scenario highlights the necessity to convert the overwhelming waste biomaterials by searching for new economic applications. Because of the abundance of palm kernel shells (PKS), the translation of PKS to activated carbon is desirable and has received substantial attention (Table 1) as it proven to be a viable and sustainable ingredient for the activated carbon (AC) preparation (Xu et al., 2017). AC can be synthesized via the physical, chemical activation process or combination of both physical and chemical method of activation. During chemical activation operation, the use of activating agents, such as $\mathrm{ZnCl}_{2}, \mathrm{KOH}$, and $\mathrm{H}_{3} \mathrm{PO}_{4}$, is vital in altering the textural features in PKS made ACs. $\mathrm{H}_{3} \mathrm{PO}_{4}$ is selected for this study due to lower environmental and toxicological challenge (Khadiran et al., 
2014). These chemical agents are desiccating naturally and affect the thermal denaturing and thwart tar formation or development during the manufacturing of the activated carbon (Sayğ11ı \& Güzel 2018).

Numerous studies, as shown in Table 1, focused on the influence of carbonization temperature and the activating agent on the physicochemical features of the activated carbon. However, studies on the effect of activation time are limited. This study aimed to examine the impact of activation time on the physical and chemical features of the produced $\mathrm{AC}$, and its adsorptive performance towards $\mathrm{Pb}(\mathrm{II})$ from liquid environment. To delineate the PKS sourced activated carbon capability in the management of lead-bearing wastewater, adsorption isotherm and kinetic data were also modeled and analyzed.

Table 1

Preparation and application of palm kernel shell based activated carbon

\begin{tabular}{ccc}
\hline Preparation method & Application & Reference \\
\hline $\begin{array}{c}\text { Physical steam activation } \\
\left(800^{\circ} \mathrm{C}\right)\end{array}$ & Palm Oil Mill Effluent & Rugayah et al. (2014) \\
$\begin{array}{c}\text { Chemical activation } \\
\left(\mathrm{ZnCl}, 550^{\circ} \mathrm{C}\right)\end{array}$ & $\mathrm{CO}_{2}$ capture & Hidayu and Muda (2016) \\
$\begin{array}{c}\text { Chemical activation } \\
\left(\mathrm{KOH}, 500-900^{\circ} \mathrm{C}\right)\end{array}$ & Andas et al. (2017) \\
$\begin{array}{c}\mathrm{Chemical} \text { activation } \\
\left(\mathrm{ZnCl}, 500-550^{\circ} \mathrm{C}, 1 \mathrm{~h}\right)\end{array}$ & Dye removal & Garcia et al. (2018) \\
$\begin{array}{c}\mathrm{Chemical} \text { activation } \\
\left(\mathrm{H}_{3} \mathrm{PO}_{4}, 550^{\circ} \mathrm{C}, 2 \mathrm{~h}\right)\end{array}$ & Water treatment & Razi et al. (2018) \\
One stage $\mathrm{CO}_{2}$ activation & $\left(\mathrm{Grey}^{2}\right.$ water $)$ & \\
\hline
\end{tabular}

\section{MATERIALS AND METHOD}

\section{Preparation and Characterization of ACs (Biosorbents)}

The PKS was impregnated first by concentrated orthophosphoric acid at the feed ratio of PKS to acid (1:2) based on weight. Measured $100 \mathrm{~g}$ of PKS powder was introduced to phosphoric acid ( $85 \%$ by weight) solution $(120 \mathrm{~mL})$ and thoroughly agitated manually. The impregnated samples were oven-dried for 24 hours at $110^{\circ} \mathrm{C}$. Then, the impregnated PKS sample $(10 \mathrm{~g})$ was thermally activated at $600^{\circ} \mathrm{C}$ in a vertical tubular furnace under 
$\mathrm{N}_{2}$ gas flow of $20 \mathrm{~mL} \mathrm{~min}^{-1}$ for predetermined duration (1 to 4 hours). The resulting AC cooled to room temperature, then rinsed severally with deionized $\mathrm{H}_{2} \mathrm{O}$, until the $\mathrm{pH}$ of the filtrate is constant, filtered, and oven-dried at $110^{\circ} \mathrm{C}$ for 24 hours. The powder activated carbon (AC) produced was denoted as AC-\#, where \# is the activation time of 1 to 4 hour.

The ACs pore diameter, volume and surface area was determined from $\mathrm{N}_{2}$ adsorptiondesorption isotherm (Quantachrome Autosorb-1) using the Brunauer-Emmet-Teller (BET) and Barrett-Joyner-Halenda (BJH) method, respectively. The iodine number and Methylene blue number was determined using standard procedures (Nunes \& Guerreiro, 2011). The $\mathrm{pH}$ drift approach was employed to determine the zero-point charge $\left(\mathrm{pH}_{\mathrm{pzc}}\right)$ of the ACs (Wang et al., 2009; Wang \& Jian, 2013).

\section{Batch Adsorption Experiments}

The lead(II) ions stock solution was prepared by adding predetermined mass of $\mathrm{Pb}\left(\mathrm{NO}_{3}\right)_{2}$ salt (Fisher Scientific, Malaysia) in 1.0 L deionized water in a volumetric flask. Prior to each experimental adsorption study, solution of various $\mathrm{Pb}$ (II) ion concentrations were made via dilution of the standard solution with deionized water. The adsorptive uptake of $\mathrm{Pb}$ (II) onto the activated carbon as a function of time, amount of adsorbent (0.1-0.6 $\mathrm{g}), \mathrm{Pb}(\mathrm{II})$ concentration (100-250 $\left.\mathrm{mg} \mathrm{L}^{-1}\right)$, initial solution $\mathrm{pH}(1-5)$ and temperature (25$50{ }^{\circ} \mathrm{C}$ ) were investigated using batch experiment. The solution $\mathrm{pH}$ was varied to the predefined value by the dropwise addition of $1.0 \mathrm{M} \mathrm{NaOH}$ or $\mathrm{HCl}$ solution. In a typical adsorption experiment, a measured quantity of AC add into $250 \mathrm{~mL}$ flasks containing $200 \mathrm{~mL}$ of identified concentration of $\mathrm{Pb}$ (II) ions. The mixture was agitated at $110 \mathrm{rpm}$ speed using a temperature-controlled water bath shaker (Memmert, Germany) for 120 min. At certain time intervals, an aliquot of the sample was collected and analyzed using an AAS spectrophotometer (Thermo Scientific-S series). All experiments were executed in triplicates at $25^{\circ} \mathrm{C}$. The extent $(\%)$ of metal uptake and the adsorption capacity was determined respectively by Equations 1 and 2 .

$$
\begin{aligned}
& \operatorname{Removal}(\%)=\frac{\left(C_{0}-C_{t}\right)}{C_{0}} \times 100 \\
& \mathrm{q}_{t}=\frac{\left(C_{0}-C_{t}\right)}{m} \times V
\end{aligned}
$$

$\mathrm{C}_{0}\left(\mathrm{mg} \mathrm{L}^{-1}\right)$ denote initial concentration of $\mathrm{Pb}(\mathrm{II})$ ions, $\mathrm{q}_{\mathrm{t}}\left(\mathrm{mg} \mathrm{g}^{-1}\right)$ and $\mathrm{C}_{\mathrm{t}}\left(\mathrm{mg} \mathrm{L}^{-1}\right)$ is the amount of $\mathrm{Pb}$ (II) adsorbed by the $\mathrm{AC}$ adsorbent and the $\mathrm{Pb}$ (II) concentration in solution at time $\mathrm{t}$, respectively. $\mathrm{V}(\mathrm{L})$ and $\mathrm{m}(\mathrm{g})$ represent respectively the volume of metal solution, and weight of AC used. 


\section{RESULTS AND DISCUSSION}

\section{Surface Characterization of Prepared AC}

The percentage yield of the produced ACs at different activation time is presented in Table 2. The decrease in the yield of AC-1 to AC-4 is due to the increased loss of volatile constituents in the PKS with longer activation time.

Table 2

$\mathrm{N}_{2}$-BET surface area and porosity of PKS activated carbons prepared at different activation times

\begin{tabular}{lcccc}
\hline Sample & $\begin{array}{c}\text { Yield } \\
(\%)\end{array}$ & $\begin{array}{c}\text { Surface Area } \\
\left(\mathrm{m}^{2} / \mathrm{g}\right)\end{array}$ & $\begin{array}{c}\text { Average Pore } \\
\mathrm{D}(\AA)\end{array}$ & $\begin{array}{c}\text { Micropore Volume } \\
\left(\mathrm{cm}^{3} / \mathrm{g}\right)\end{array}$ \\
\hline $\mathrm{AC}-1$ & 47.4 & 1059 & 21.631 & 0.6442 \\
$\mathrm{AC}-2$ & 44.3 & 1083 & 25.290 & 0.6956 \\
$\mathrm{AC}-3$ & 42.6 & 1004 & 22.557 & 0.0625 \\
$\mathrm{AC}-4$ & 39.8 & 1040 & 21.092 & 0.5551 \\
\hline
\end{tabular}

The adsorption and desorption isotherm of $\mathrm{N}_{2}$ at $-196^{\circ} \mathrm{C}$ of the prepared activated carbons is shown in Figure 1. Both AC-1 and AC-2 exhibited the typical type I isotherm as IUPAC classification, which suggests a predominantly microporous structure activated carbon. However, at prolonged activation time, the adsorption isotherm showed type IV isotherm and a small hysteresis loop, indicating the development of mesopores in the sample. Figure 2 displays the distribution of pore size of the prepared ACs, confirmed the change in the porosity of the ACs from microporous to micro-mesoporous with longer activation period. Table 2 also reveals that the surface area and the porosity of the ACs increase with increasing activation time up to $2 \mathrm{~h}$ before it decreases at prolonged activation time. This result shows that the number of micropores increases initially, which corresponds to the increased surface area but then collapsed to form mesopores, bring about a shrinkage in the surface area of the AC.

The amounts of micropores and mesopores of the prepared ACs can be deduced from iodine value and methylene blue (MB) value, respectively. Figure 3 depicts the iodine and MB sorption onto the PKS based activated carbon samples. The iodine and MB adsorption capacity increased by $15 \%$ and $10 \%$ when the activation time is prolonged from 1 to $4 \mathrm{~h}$. This result indicates a small change in porosity with lengthier activation time, this agreed with the previous report of Mopoung et al. (2015). A slight reduction in iodine value at 4 $\mathrm{h}$ activation time could be probably associated to the collapse of the micropores to form mesopores. 


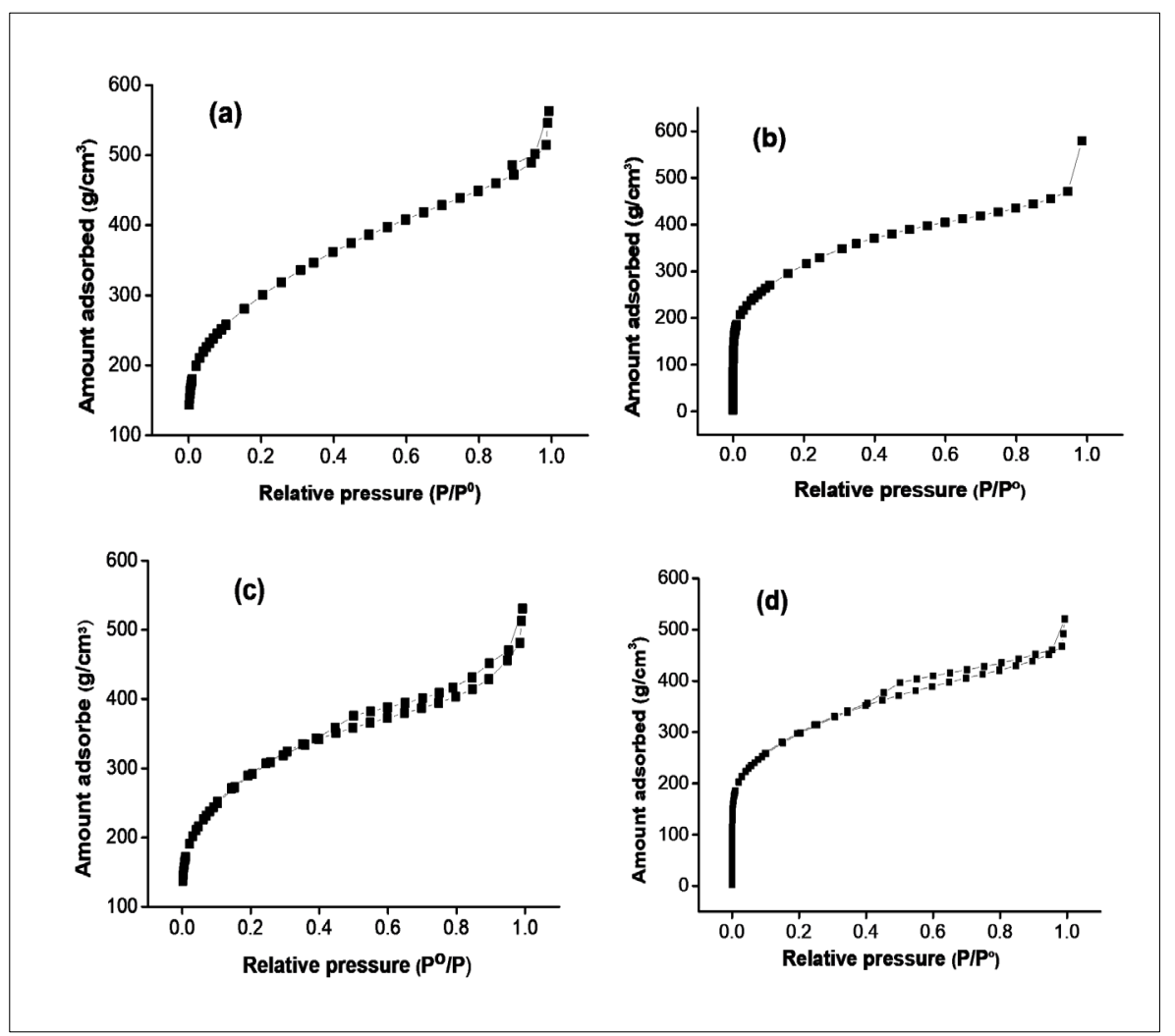

Figure 1. $\mathrm{N}_{2}$ adsorption-desorption isotherm for (a) AC-1, (b) AC-2, (c) AC-3 and (d) AC-4

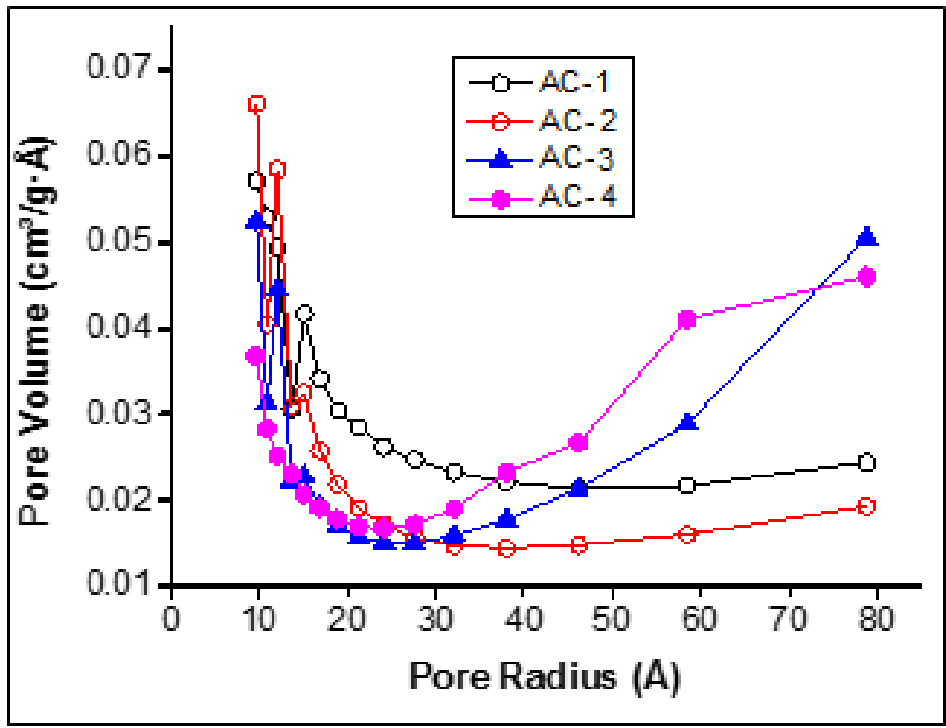

Figure 2. Pore size distribution of the prepared ACs 


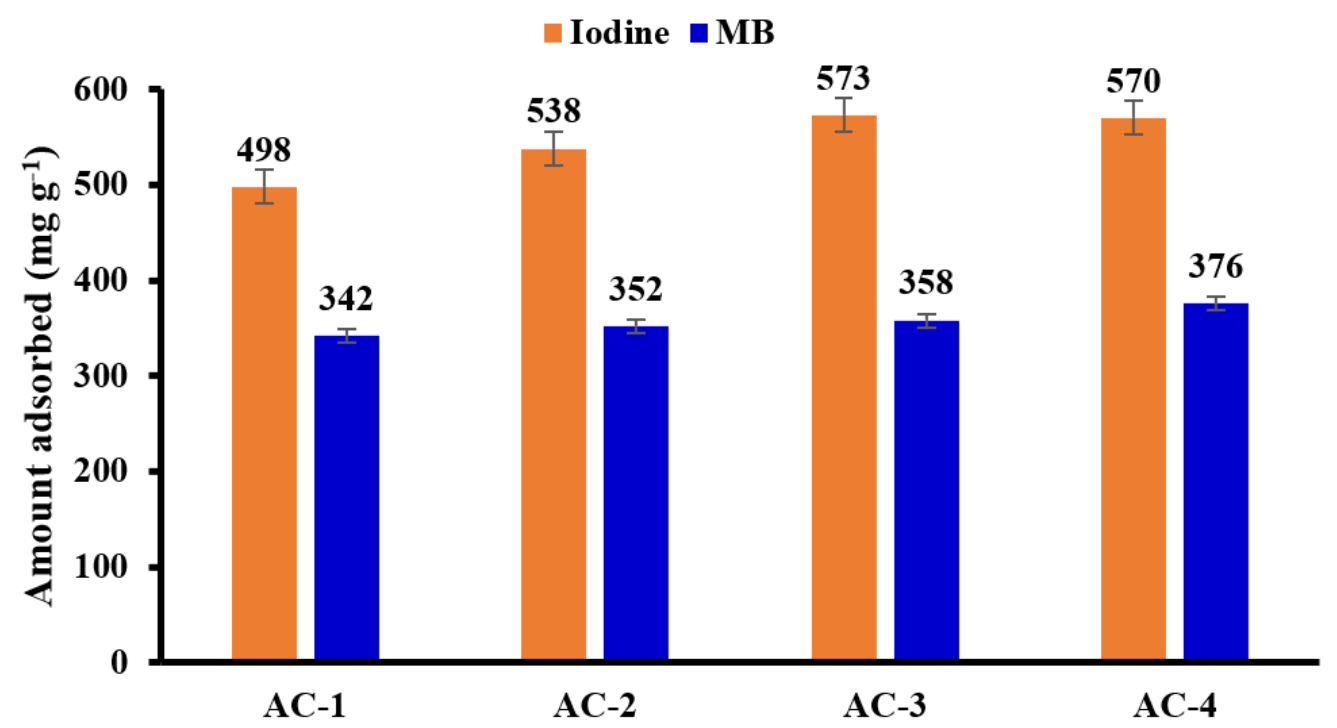

Figure 3. Iodine and MB uptake by various AC samples

\section{Adsorption Performance of Activated Carbon}

To select the best adsorbent, the produced ACs were screened by adsorbing $\mathrm{Pb}$ (II) ion in batch adsorption studies. Figure 4 depicts that there is insignificant variance in the $\mathrm{Pb}$ (II) ion uptake by AC-3 and AC-4. In this work, AC-4 was selected as an adsorbent for other experiments due to highest adsorption capacity.

Figure 5 shows the extent (in \%) of $\mathrm{Pb}$ (II) removal and the AC-4 sorption capacity, as a function of adsorbent quantity. The percentage $\mathrm{Pb}$ (II) sequestration increased as the $\mathrm{AC}$ dose increases to $0.2 \mathrm{~g}$ but remained quite constant with further mass increment. This observation could be due to the agglomeration of adsorbent, inhibiting $\mathrm{Pb}$ (II) from attaching to the AC surface. However, the adsorption capacity $\left(q_{e}\right)$ presented the opposite trend. The decline is attributable to the growing number of vacant sites as the ratio of lead (II) ions to the sorption sites reduces with increasing AC doses (Amarasinghe \& Williams, 2007). Judging by both the extent of lead uptake and the amount adsorbed, the optimum AC weight for the separation experiment is selected as $0.13 \mathrm{~g}$.

Figure 6 illustrates the time and initial lead (II) concentration as parameters that influence the uptake $\mathrm{Pb}(\mathrm{II})$ by $\mathrm{AC}$. The removal extent decreases as the initial concentration of $\mathrm{Pb}$ (II) ion increases, while the quantity adsorbed increases. With a fixed amount of $\mathrm{AC}$, the number of available vacant sites is constant. At low concentration of metal ion, the ratio of adsorption sites to lead ion is large, leading to a high percentage of removal (Figure $6 \mathrm{~A})$. However, this ratio becomes smaller at high metal concentration, ensuing into a lower 


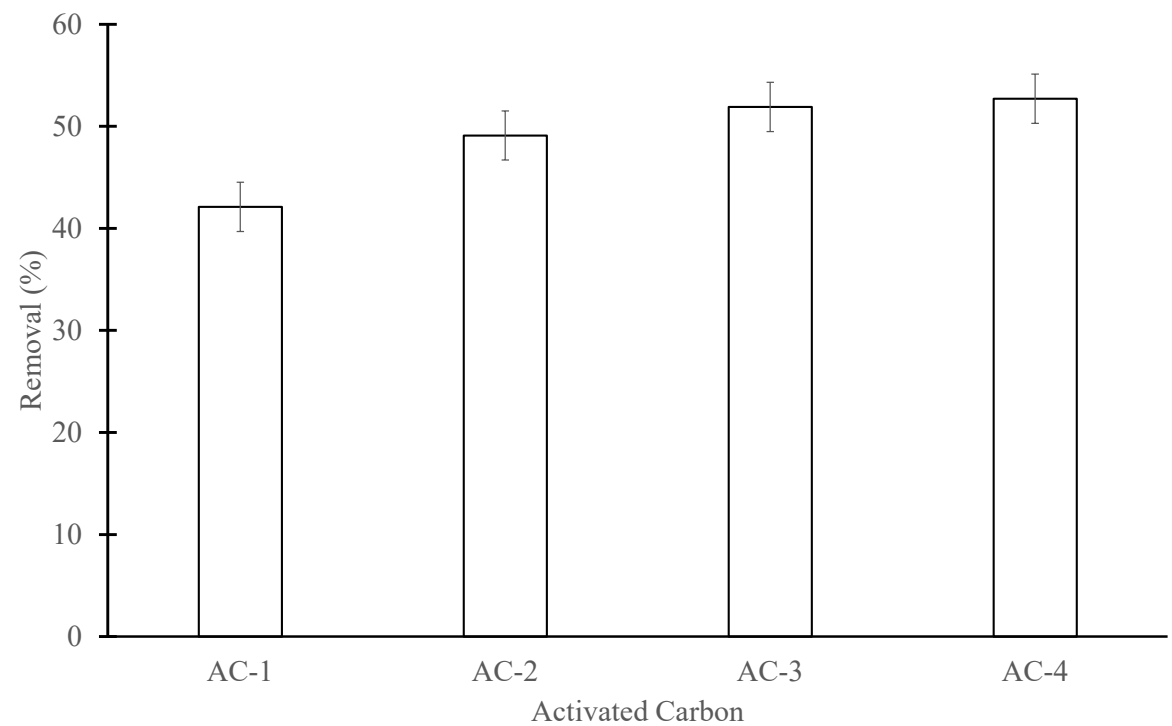

Figure 4. Removal of $\mathrm{Pb}$ by activated carbon prepared at different activation time

(Condition: $50 \mathrm{mg} \mathrm{L}^{-1}$ of $\mathrm{Pb}(\mathrm{II}) ; 0.1 \mathrm{~g}$ of $\mathrm{AC}, \mathrm{pH}$ of solution =4)

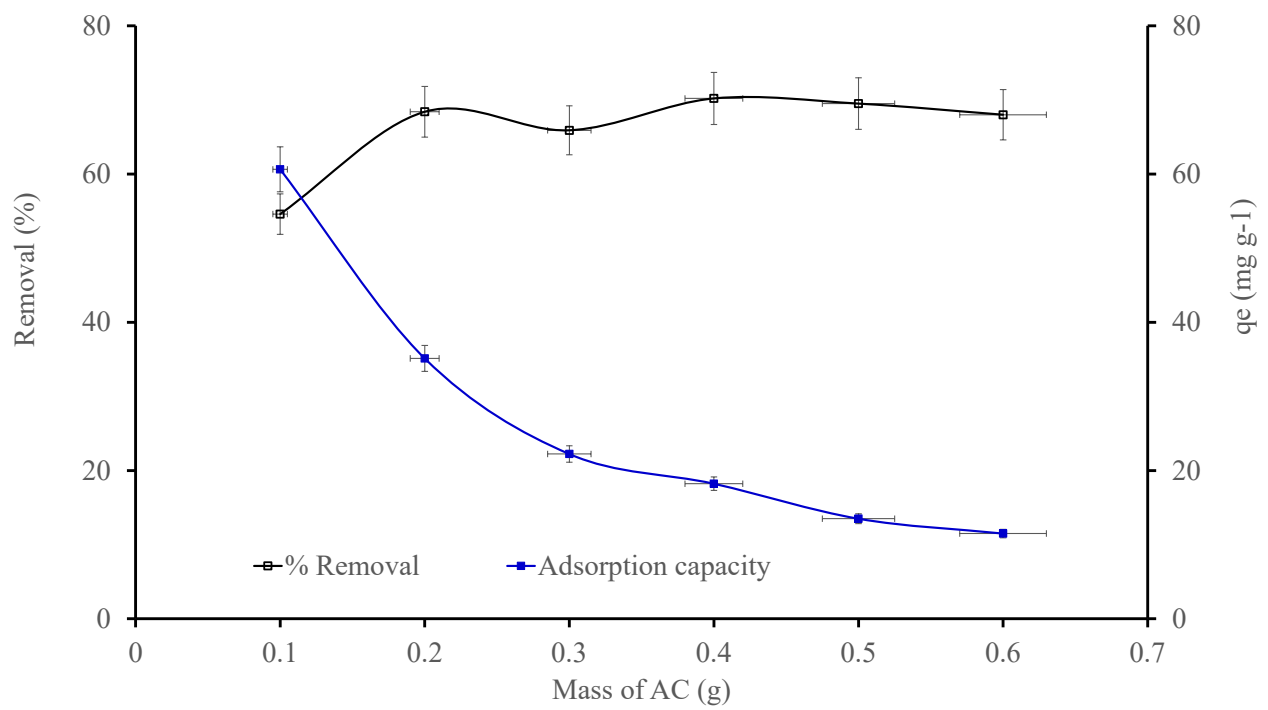

Figure 5. Extent of $\mathrm{Pb}(\mathrm{II})$ ion uptake and adsorption capacity of AC-4 at different adsorbent dosage. (Pb(II) $=50 \mathrm{mg} \mathrm{L}^{-1}$; Solution $\mathrm{pH}=4$ ) 
percentage lead removal. In the same vein, as the lead concentration increases, the driving power to subdue the resistance between metal ion in aqueous phase and solid sorbent phases becomes stronger, culminate to rise in adsorption capability. The adsorption ability increased rapidly up during the first 40 min contact time of the experiment as revealed in Figure 6B. This is associated to the handiness of a greater number of unoccupied sorption sites. It then gradually decreased because of repulsion forces between the attached metal ions and the ions present in the mixture, eventually equilibrium is attained as the solid surface become saturated.
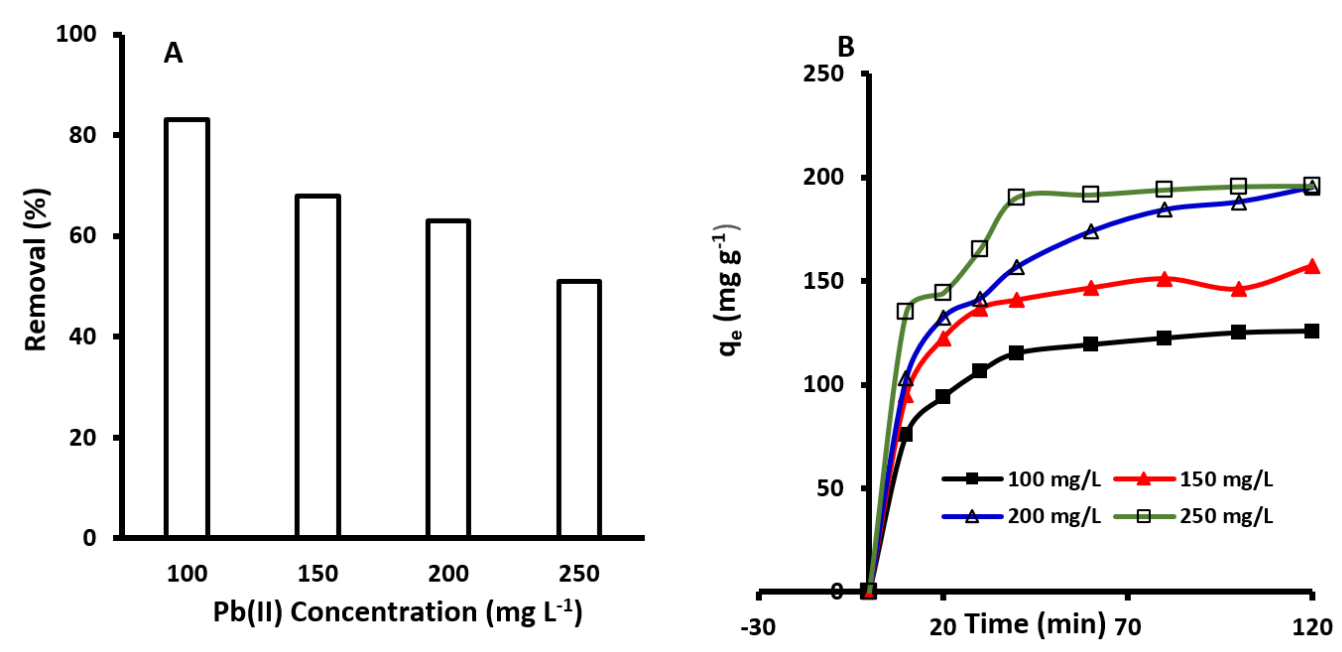

Figure 6. The adsorption of various concentration of $\mathrm{Pb}(\mathrm{II})$ ions on AC-4 (Condition: $0.13 \mathrm{~g} \mathrm{AC}-4$, $\mathrm{pH}$ of solution $=4$ )

The $\mathrm{pH}$ has an essential influence on the separation of metals because it defines the charge on adsorbent surface, the ionization extent, and speciation of adsorbate (Mouni et al., 2011). The $\mathrm{pH}$ of point zero charge, $\mathrm{pH}_{\mathrm{pzc}}$, of the $\mathrm{AC}-4$, as estimated using the $\mathrm{pH}$ drift method, was 2.8, which implies that the biosorbent surface was charged positively at $\mathrm{pH}<2.8$ and negatively charged at $\mathrm{pH}$ higher than 2.8. Since lead ions are well-known for precipitation $\left[\mathrm{Pb}(\mathrm{OH})_{2}\right]$ at $\mathrm{pH}$ greater than 7 , the impact of solution $\mathrm{pH}$ on $\mathrm{Pb}$ (II) ions entrapment onto AC-4 was examined in 1-5 pH range (Figure 7).

The quantity of lead ion adsorbed was found low in highly acidic environments $(\mathrm{pH}$ 1-2) owing to existence of electrostatic revulsion between metal ions and positively charged AC-4 surface. Moreover, struggle for the vacant sites between the abundantly available $\mathrm{H}^{+}$ions and $\mathrm{Pb}(\mathrm{II})$ ion, also propelled reduction in $\mathrm{Pb}$ (II) uptake. The uptake of lead ion is more significant at a $\mathrm{pH}$ range of 3 to 5 , with the highest sorption capacity of $93 \mathrm{mg} \mathrm{g}^{-1}$ 
observed at $\mathrm{pH}$. The enhancement of the quantity of adsorbed $\mathrm{Pb}(\mathrm{II})$ was induced by the electrostatic attraction between the metal ion and the AC-4 negatively charged surface. This phenomenon was also described by Zaini et al. (2009) in batch entrapment of lead unto cattle-manure-compost based $\mathrm{AC}$. A decline in $\mathrm{Pb}(\mathrm{II})$ removal was witnessed at $\mathrm{pH}$ above 4 , this is due to soluble hydroxide complexes formation.

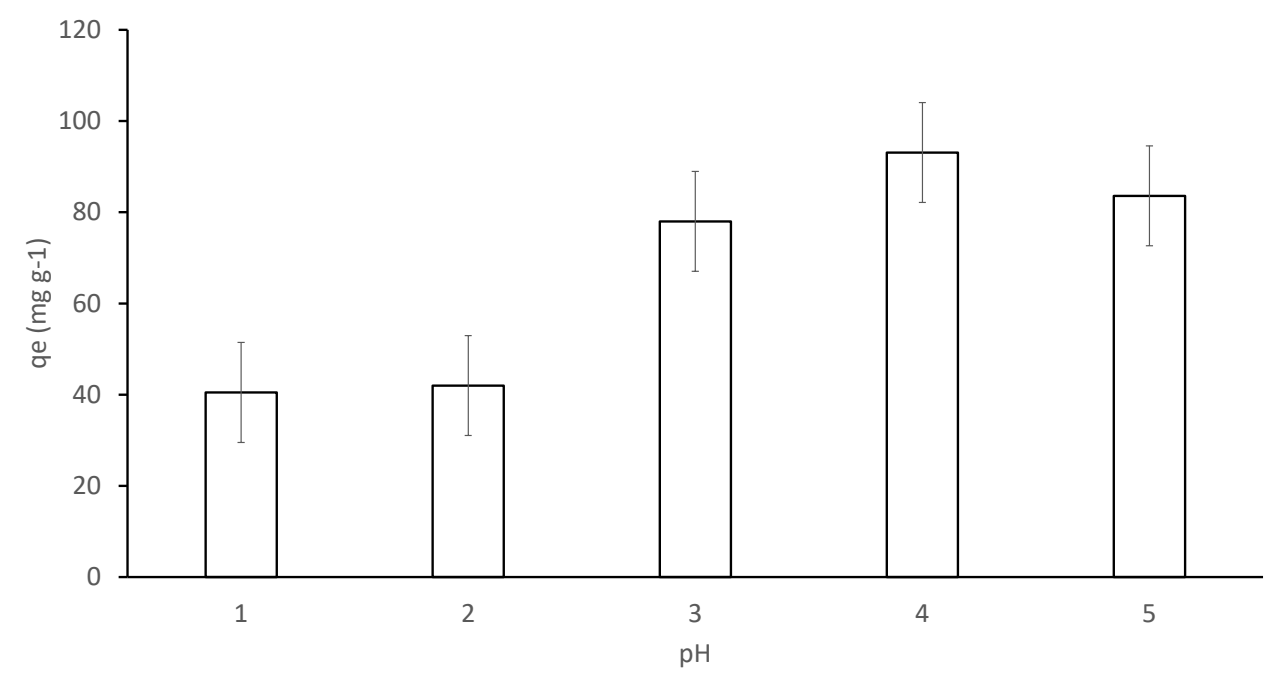

Figure 7. Sequestration of $\mathrm{Pb}(\mathrm{II})$ on $\mathrm{AC}-4$ at different $\mathrm{pH}$ of the $\mathrm{Pb}$ (II) solution (Condition: $0.13 \mathrm{~g} \mathrm{AC}-4 ; 80$ $\left.\mathrm{mg} \mathrm{L}^{-1} \mathrm{~Pb}(\mathrm{II})\right)$

\section{Adsorption Isotherm, Kinetics, and Thermodynamics}

To delineate the lead ions sequestration pattern, the adsorption behavior of lead on AC-4 was explored by fitting the experimental data to the Langmuir and Freundlich adsorption isotherm model. The linear form of the two models is respectively, represented by Equation 3 and 4.

$$
\begin{aligned}
& \frac{\mathrm{C}_{e}}{q_{e}}=\frac{1}{K_{L} q_{m}}+\frac{1}{q_{m}} C_{e} \\
& \log q_{e}=\log K_{F}+\frac{1}{n} \log C_{e}
\end{aligned}
$$

$\mathrm{C}_{\mathrm{e}}$ and $\mathrm{q}_{\mathrm{e}}$ represents the concentration $\left(\mathrm{mg} \mathrm{L}^{-1}\right)$ of lead ions, and the quantity $\left(\mathrm{mg} \mathrm{g}^{-1}\right)$ of $\mathrm{Pb}$ (II) ion entrapped at equilibrium. $\mathrm{q}_{\mathrm{m}}$ is the Langmuir maximum adsorption capacity $(\mathrm{mg}$ $\left.\mathrm{g}^{-1}\right) . \mathrm{K}_{\mathrm{L}}$ represents the Langmuir parameter $\left(\mathrm{L} \mathrm{mg}^{-1}\right)$ associated with the binding site affinity. $\mathrm{n}$ and $\mathrm{K}_{\mathrm{F}}$ are Freundlich constants associated with the intensity and sorption capacity, 
respectively. The results presented in Figure 8 and Table 3 show that the Langmuir model provides a well fit with a $\mathrm{R}^{2}$-value of 0.992 , signifying a monolayer adsorption process. However, the possibility of multi-layer adsorption is not ruled out based on the $\mathrm{R}^{2}$ value greater than 0.8 as indicated by Table 3 .
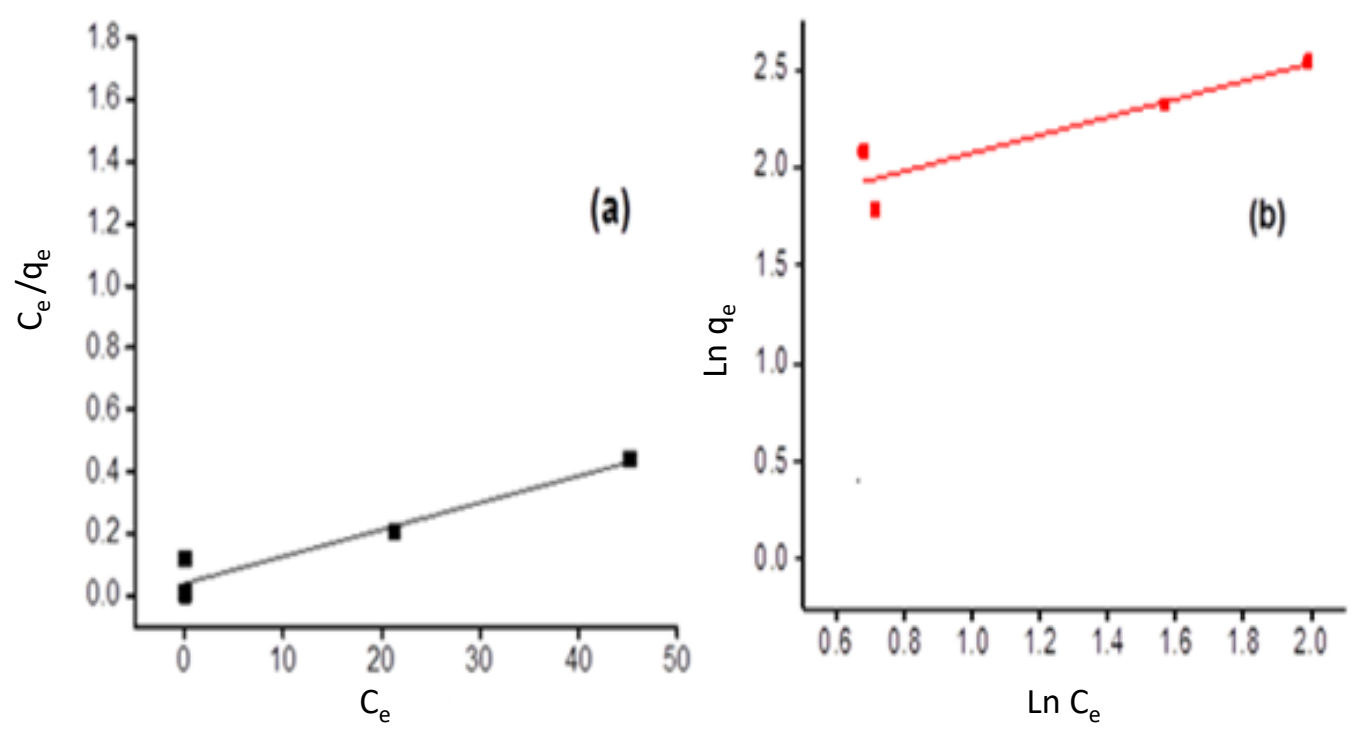

Figure 8. Adsorption isotherm of $\mathrm{Pb}$ (II) linearized according to (a) Langmuir (b) Freundlich

Table 3

Isotherm parameters for $\mathrm{Pb}(\mathrm{II})$ sequestration onto $A C-4$

\begin{tabular}{lcccccc}
\hline & \multicolumn{3}{c}{ Langmuir isotherm } & \multicolumn{3}{c}{ Freundlich isotherm } \\
\cline { 2 - 7 } AC-4 & $\mathrm{q}_{\mathrm{m}}\left(\mathrm{mg} \mathrm{g}^{-1}\right)$ & $\mathrm{K}_{\mathrm{L}}\left(\mathrm{L} \mathrm{mg}^{-1}\right)$ & $\mathrm{R}^{2}$ & $\mathrm{~K}_{\mathrm{F}}$ & $\mathrm{n}$ & $\mathrm{R}^{2}$ \\
\cline { 2 - 7 } & 222.22 & 0.067 & 0.992 & 59.43 & 3.85 & 0.843 \\
\hline
\end{tabular}

The adsorption experimental data were also fitted to proven kinetics models; pseudofirst order (PFO), pseudo-second order (PSO), and intraparticle diffusion (IPD), to analyse the adsorption mechanism and estimate the reaction rate constant. The linearized form of the PFO and PSO kinetic models are presented, accordingly in Equations 5 and 6.

$$
\begin{aligned}
& \ln \left(q_{e}-q_{t}\right)=\ln q_{e}-k_{1} t \\
& \frac{\mathrm{t}}{\mathrm{q}_{\mathrm{t}}}=\frac{1}{\mathrm{k}_{2} \mathrm{q}_{\mathrm{e}}^{2}}+\frac{1}{\mathrm{q}_{\mathrm{e}}} \mathrm{t}
\end{aligned}
$$


where $k_{1}$ and $k_{2}$ represent the rate constant for the PFO and PSO, while $q_{e}$ and $q_{t}$ denote respectively the quantity of lead ions adsorbed at equilibrium and at any specified time t. The model constants, sorption capacities, and the correlation coefficient $\left(\mathrm{R}^{2}\right)$ for the $\mathrm{Pb}(\mathrm{II})$ ion uptake at different concentrations, on AC-4 are presented in Table 4. According to $\mathrm{R}^{2}$ values and the excellent closeness of the calculated $\mathrm{q}_{\mathrm{e}}$ to the experimental $\mathrm{q}_{\mathrm{e}}$, the adsorption data fitted the PSO kinetics well, indicating that the sorption process is ruled by the handiness of the vacant adsorption sites than the lead ion concentrations (Arshadi et al., 2014). The entrapment process strongly involved complexation of metal ions with the binding sites on AC-4. Hence, chemical adsorption is assumed the rate controlling step.

The impact of diffusion in the mechanism of lead ion uptake was analyzed employing the intra-particle diffusion (IPD) model, in which its linear form is defined by Equation 7.

$$
\mathrm{q}_{t}=k_{i d} t^{1 / 2}+C
$$

$\mathrm{k}_{\mathrm{id}}$ is the intra-particle diffusion rate constant $\left(\mathrm{mg} \mathrm{g}^{-1} \cdot \mathrm{min}^{-1 / 2}\right)$, and $\mathrm{C}$ is attributed to the boundary layer depth. The IPD model plot, Figure 9 illustrated multilinearities throughout the whole-time range, an indication of a multi-step sorption process. The initial first step is due to the entrapment of lead onto the adsorbent's surface through boundary layer diffusion (Abdelwahab et al., 2013), while the subsequent adsorption step is attributed to the pore diffusion of metal ions into the solid adsorbent where the rate controlling step is IPD (Gao et al., 2013).

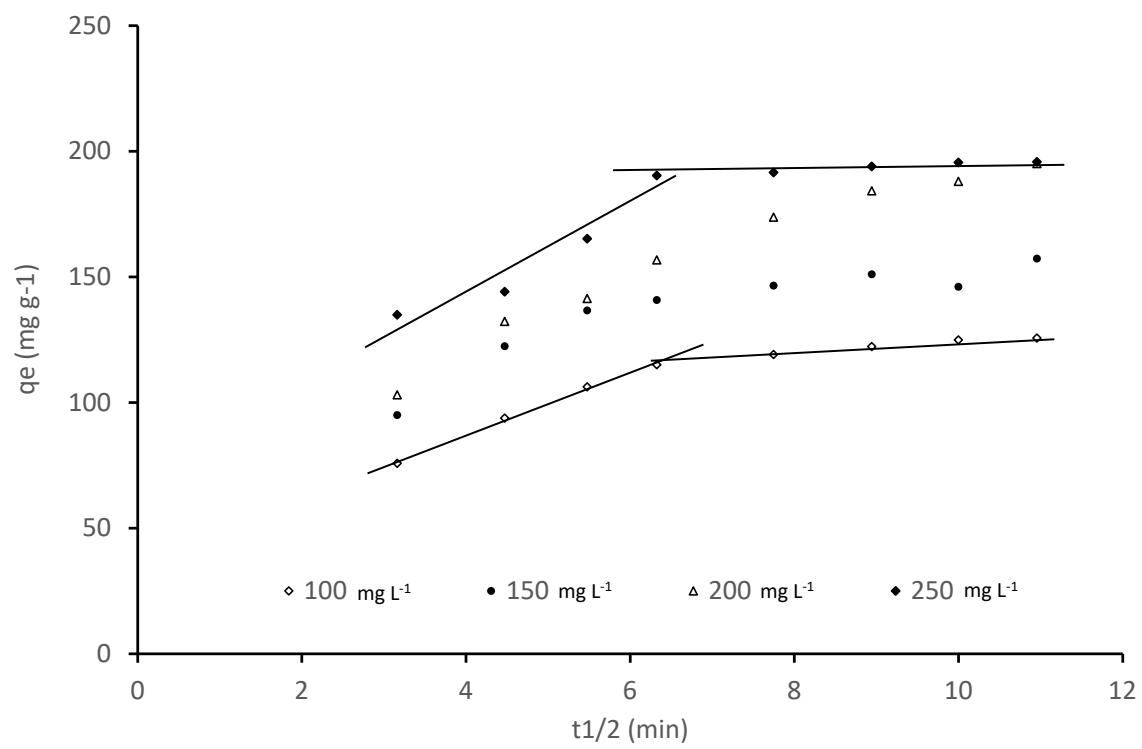

Figure 9. The IPD modeling of $\mathrm{Pb}$ uptake by AC-4 at varied concentrations (Initial $\mathrm{pH}=4$; ads. dosage $=0.13 \mathrm{~g}$ ) 
Table 4

Kinetics parameters for sequestration of lead (II) on AC-4

\begin{tabular}{lllll}
\hline $\mathbf{C}_{\mathbf{0}}\left(\mathbf{m g ~ ~ L ^ { - 1 }}\right)$ & 100 & 150 & 200 & 250 \\
$\mathrm{q}_{\mathrm{e}}$, expt. $\left(\mathrm{mg} \mathrm{g}^{-1}\right)$ & 125.7 & 157.4 & 195.1 & 195.9
\end{tabular}

\section{PFO}

$\begin{array}{lllll}\mathrm{q}_{\mathrm{e}} \text {, calc. }\left(\mathrm{mg} \mathrm{g}^{-1}\right) & 86.5 & 90.6 & 119.8 & 91.2 \\ \mathrm{k}_{1}\left(\min ^{-1}\right) & 0.0514 & 0.0450 & 0.0286 & 0.0344 \\ \mathrm{R}^{2} & 0.9949 & 0.9672 & 0.9925 & 0.9164\end{array}$

\section{PSO}

$\begin{array}{lllll}\mathrm{q}_{\mathrm{e}}, \text { calc. }\left(\mathrm{mg} \mathrm{g}^{-1}\right) & 135.1 & 161.3 & 212.8 & 208.3 \\ \mathrm{k}_{2}\left(\mathrm{~g} \mathrm{mg-}^{-1} \mathrm{~min}^{-1}\right) & 9.54 \times 10^{-4} & 9.61 \times 10^{-4} & 3.57 \times 10^{-4} & 7.68 \times 10^{-4} \\ \mathrm{R}^{2} & 0.9998 & 0.9972 & 0.9985 & 0.9983\end{array}$

\section{IPD}

\begin{tabular}{lllll}
$\mathrm{k}_{1}$ & 12.49 & 18.13 & 15.10 & 17.35 \\
$\mathrm{R}^{2}$ & 0.9966 & 0.9892 & 0.9804 & 0.9174 \\
$\mathrm{k}_{2}$ & 2.37 & 3.11 & 6.34 & 1.30 \\
$\mathrm{R}^{2}$ & 0.9781 & 0.8114 & 0.9758 & 0.9612 \\
\hline
\end{tabular}

Adsorption thermodynamics of $\mathrm{Pb}$ (II) on AC-4 was study by carrying out the adsorption experiment at different temperatures. The thermodynamic parameters, namely Gibb's free energy $\left(\Delta \mathrm{G}^{\circ}\right)$, enthalpy $\left(\Delta \mathrm{H}^{\circ}\right)$ and entropy $\left(\Delta \mathrm{S}^{\circ}\right)$ associated with the $\mathrm{Pb}$ (II) uptake, were calculated with the aid of Equations 8-10:

$$
\begin{aligned}
& \Delta \mathrm{G}^{\mathrm{o}}=-\mathrm{RT} \text { In } \mathrm{K}_{\mathrm{C}} \\
& \text { In } \mathrm{K}_{\mathrm{C}}=\left(\frac{\Delta \mathrm{S}}{\mathrm{R}}\right)-\left(\frac{\Delta \mathrm{H}}{\mathrm{R}}\right) \frac{1}{\mathrm{~T}} \\
& \mathrm{~K}_{\mathrm{C}}=C_{\mathrm{ads}} / C_{\mathrm{sol}}
\end{aligned}
$$

$R$ represent the universal gas constant, $K_{C}$ denote the equilibrium constant, and $C_{\text {ads }}$ and $\mathrm{C}_{\text {sol }}$ is the concentration of $\mathrm{Pb}(\mathrm{II})$ adsorbed on the $\mathrm{AC}-4$ and present in the solution at equilibrium, respectively. By using van't Hoff plot (Figure 10), the $\Delta \mathrm{H}^{\circ}$ and $\Delta \mathrm{S}^{\circ}$ can be estimated from the gradient and intercept of the linear graph. $\Delta \mathrm{G}^{\circ}, \Delta \mathrm{H}^{\circ}$, and $\Delta \mathrm{S}^{\circ}$ deduced are presented in the inset of Figure 9. With increasing temperature, the $\Delta \mathrm{G}^{\circ}$ value became more negative, indicating the increase in the degree of spontaneity, attributed to the increased 
mobility and diffusion of the ions into the adsorbent's pore sites. As for enthalpy, the value is negative and fall between 2.1 and $20 \mathrm{~kJ} \mathrm{~mol}^{-1}$, designating that uptake of lead(II) ion by AC-4 is a physical sorption process and exothermic (in nature). Furthermore, there is decline in the randomness at the $\mathrm{AC}$ sorbent- $\mathrm{Pb}(\mathrm{II})$ adsorbate solution interface during $\mathrm{Pb}$ (II) uptake as revealed by the negative entropy value. This is consistent with the report by Hannachi et al. (2019) on the separation of cadmium ions from aqueous environment with novel xerogel adsorbents.

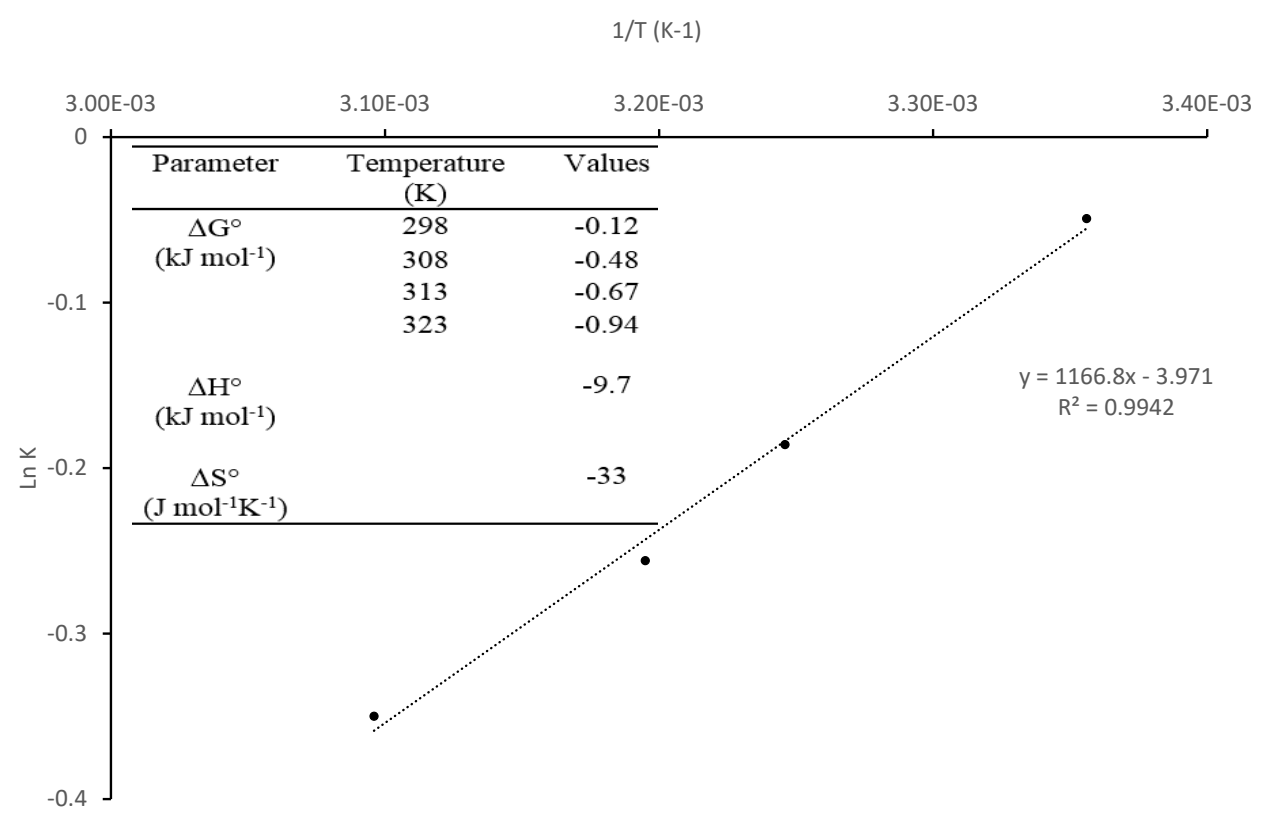

Figure 10. Vant Hoff plot for $\mathrm{Pb}(\mathrm{II})$ uptake and the thermodynamic parameters

The sorption capacity of AC-4 is compared with previous work reported in the literature (Table 5) in evaluating the potential use of the AC derived from the palm kernel shell to remove $\mathrm{Pb}(\mathrm{II})$ in water. The $\mathrm{AC}-4$ shows higher capacities for lead removal compared to activated carbons derived from other agro-wastes. The significant variation in the adsorbent capacity could be due to the precursor properties, the methods in the synthesis of the AC, and the experimental adsorption conditions used. 
Table 5

Adsorption capacities $\left(q_{m}\right)$ of lead(II) ion with various agro-waste sourced ACs.

\begin{tabular}{lccc}
\hline AC & $\begin{array}{c}\text { Experimental } \\
\text { Conditions }\end{array}$ & $\begin{array}{c}\mathrm{Q}_{\mathrm{m}} \\
\left(\mathrm{mg} \mathrm{g}^{-1}\right)\end{array}$ & References \\
\hline $\begin{array}{l}\text { palm shell activated } \\
\text { carbon }\end{array}$ & $\begin{array}{c}\text { Dosage }: 0.65 \mathrm{~g} \mathrm{~L}^{-1} ; \\
\mathrm{pH} 4 ; \text { T:25 }\end{array}$ & 222.22 & This study \\
$\begin{array}{l}\text { Hazelnut husks } \\
\text { activated carbon } \\
\text { Dosage }: 12 \mathrm{~g} \mathrm{~L}^{-1} ; \\
\mathrm{pH}: 6.7 ; \mathrm{T}: 28^{\circ} \mathrm{C}\end{array}$ & 13.05 & Imamoglu and Oktay (2008) \\
carbon & $\begin{array}{l}\text { Dosage }: 10 \mathrm{~g} \mathrm{~L}^{-1} ; \\
\mathrm{pH}: 5 ; \mathrm{T}: 25^{\circ} \mathrm{C}\end{array}$ & 71.430 & $\begin{array}{c}\text { Baylan and Meriçboyu } \\
(2016)\end{array}$ \\
$\begin{array}{l}\text { Coffee waste } \\
\text { residue activated } \\
\text { carbon }\end{array}$ & $\begin{array}{c}\text { Dosage }: 1 \mathrm{~g} \mathrm{~L}^{-1} ; \\
\mathrm{pH}: 5 ; \mathrm{T}: 27^{\circ} \mathrm{C}\end{array}$ & 95.2 & Yeung et al. (2014) \\
$\begin{array}{l}\text { Bamboo activated } \\
\text { carbon }\end{array}$ & $\begin{array}{c}\text { Dosage: } 10 \mathrm{~g} / \mathrm{L} ; \\
\mathrm{pH}: 7 ; \mathrm{T}: 27^{\circ} \mathrm{C}\end{array}$ & 124.2 & Ademiluyi and Nze (2016) \\
\hline
\end{tabular}

\section{CONCLUSION}

Conversion of PKS to microporous AC biosorbents was successful via the chemical and thermal activation method. Although, extension of the activation period beyond 2 hours ensued in the collapse of micropores to mesopore, the surface area of the activated carbons was not significantly affected. The activated carbon produced after 4 hours of activation time (AC-4) exhibited the highest adsorption capacity towards lead metal uptake from aqueous solution. The suited optimum condition for the sequestration of $\mathrm{Pb}(\mathrm{II})$ was $0.13 \mathrm{~g} \mathrm{AC}-4$, $250 \mathrm{mg} / \mathrm{L} \mathrm{Pb}$ (II) solution, and $\mathrm{pH}$ 4. The entrapment of $\mathrm{Pb}$ (II) on AC-4, was spontaneous and exothermic. The adsorption fitted the Langmuir adsorption model, with a maximum adsorption capacity of $222 \mathrm{mg} / \mathrm{g}$, and the pseudo-second-order kinetics model signifying chemisorption between biosorbents and lead molecules. The produced activated carbon is efficient in removing heavy metal ions in the aqueous environment and could be used as promising adsorbent for the removal of lead ion during wastewater and water treatment.

\section{ACKNOWLEDGEMENT}

The authors appreciate the Institute of Advanced Technology and Chemistry Department, Faculty of Science, Universiti Putra Malaysia (UPM) for the research facilities.

\section{REFERENCES}

Abdelwahab, O., Amin, N. K., \& El-Ashtoukhy, E. S. Z. (2013). Removal of zinc ions from aqueous solution using a cation exchange resin. Chemical Engineering Research and Design, 91(1), 165-173. https://doi. org/10.1016/j.cherd.2012.07.005 
Ademiluyi, F. T., \& Nze, J. C. (2016). Multiple adsorption of heavy metal ions in aqueous solution using activated carbon from nigerian bamboo. International Journal of Research in Engineering and Technology, 5(1), 164-169. https://doi.org/10.15623/ijret.2016.0501033

Amarasinghe, B. M. W. P. K., \& Williams, R. A. (2007). Tea waste as a low cost adsorbent for the removal of $\mathrm{Cu}$ and $\mathrm{Pb}$ from wastewater. Chemical Engineering Journal, 132(1-3), 299-309. https://doi.org/10.1016/j. cej.2007.01.016.

Andas, J., Rahman, M. L. A., \& Yahya, M. S. M. (2017). Preparation and characterization of activated carbon from palm kernel shell. In IOP Conference Series: Materials Science and Engineering (Vol. 226, No. 1, p. 012156). IOP Publishing. https://doi.org/10.1088/1757-899X/226/1/012156

Arshadi, M., Amiri, M. J., \& Mousavi, S. (2014). Kinetic, equilibrium and thermodynamics investigation of $\mathrm{Ni}(\mathrm{II}), \mathrm{Cd}(\mathrm{II}), \mathrm{Cu}(\mathrm{II})$ and $\mathrm{Co}(\mathrm{II})$ adsorption on barley straw ash. Water Resource and Industry, 6, 1-17. https://doi.org/10.1016/j.wri.2014.06.001.

Baylan, N., \& Meriçboyu, A. E. (2016). Adsorption of lead and copper on bentonite and grapeseed activated carbon in single- and binary-ion systems. Separation Science and Technology, 51(14), 2360-2368. 10.1080/01496395.2016.1212888.

EPA. (2017). National primary drinking water regulations. United States Environmental Protection Agency.

Gao, J. J., Qin, Y. B., Zhou, T., Cao, D. D., Xu, P., Hochstetter, D., \& Wang, Y. F. (2013). Adsorption of methylene blue onto activated carbon produced from tea (Camellia sinensis L.) seed shells: Kinetics, equilibrium, and thermodynamics studies. Journal of Zhejiang University Science B, 14(7), 650-658. https://doi.org/10.1631/jzus.B12a0225.

Garcia, J. R., Sedron, U., Zaini, M. A. A., \& Zakaria, Z. A. (2018). Preparation, characterization and dye removal study of carbon prepared from palm kernel shell. Environmental Science and Pollution Research, 25(6), 5076-5085. https://doi.org/10.1007/s11356-017-8975-8

Hannachi, Y., Hafidh, A., \& Ayed, S. (2019). Effectiveness of novel xerogels adsorbents for cadmium uptake from aqueous solution in batch and column modes: Synthesis, characterization, equilibrium, and mechanism analysis. Chemical Engineering and Design, 143, 11-23. https://doi.org/10.1016/j. cherd.2019.01.006

Hidayu, A. R., \& Muda, N. (2016). Preparation and characterization of impregnated activated carbon from palm kernel shell and coconut shell for $\mathrm{CO}_{2}$ capture. Procedia Engineering, 148, 106-113. https://doi. org/10.1016/j.proeng.2016.06.463

Imamoglu, M., \& Oktay, T. (2008). Removal of copper (II) and lead (II) ions from aqueous solutions by adsorption on activated carbon from a new precursor hazelnut husks. Desalination 228(1-3), 108-113. https://doi.org/10.1016/j.desal.2007.08.011.

Khadiran, T., Hussein, M. Z., Zainal, Z., \& Rusli, R. (2014). Textural and chemical properties of activated carbon prepared from tropical peat soil by chemical activation method. BioResources, 10(1), 986-1007. https://doi.org/10.15376/biores.10.1.986-1007

Krika, F., Azzouz, N., \& Ncibi, M. C. (2016). Adsorptive removal of cadmium from aqueous solution by cork biomass: Equilibrium, dynamics and thermodynamic studies. Arabian Journal of Chemistry, 9 , S1077-S1083. https://doi.org/10.1016/j.arabjc.2011.12.013 
Malik, D. S., Jain, C. K., \& Yadav, A. K. (2016). Removal of heavy metals from emerging cellulosic low-cost adsorbents : A review. Applied Water Science 7, 2113-2136. https://doi.org/10.1007/s13201-016-0401-8.

Mopoung, S., Inkum, S., \& Anuwetch, L. (2015). Effect of temperature on micropore of activated carbon from sticky rice straw by $\mathrm{H}_{3} \mathrm{PO}_{4}$ activation. Carbon-Science and Technology, 7(3), 24-29.

Mouni, L., Merabet, D., Bouzaza, A., \& Belkhiri, L. (2011). Adsorption of Pb(II) from aqueous solutions using activated carbon developed from apricot stone. Desalination, 276(1-3), 148-53. https://doi.org/10.1016/j. desal.2011.03.038

Nunes, C. A., \& Guerreiro, M. C. (2011). Estimation of surface area and pore volume of activated carbon by methylene blue and iodine numbers. Quimica Nova, 34(3), 472-476. https://doi.org/10.1590/S010040422011000300020

Poudel, J., Ohm, T. I., Gu, J. H., Shin, M. C., \& Oh, S. C. (2017). Comparative study of torrefaction of empty fruit bunches and palm kernel shell. Journal of Material Cycles and Waste Management, 19(2), 917-927. https://doi.org/10.1007/s10163-016-0492-1

Rashidi, N. A., \& Yusuf, S. (2019). Production of palm kernel shell-based activated carbon by direct physical activation for carbon dioxide adsorption. Environmental Science and Pollution Research, 26(33), 3373233746. https://doi.org/10.1007/s11356-018-1903-8

Razi, M. A. M., Al-Gheethi, A., Al-Qaini, M., \& Yousef, A. (2018). Efficiency of activated carbon from kernel shell for treatment of grey water. Arab Journal of Basic and Applied Sciences, 25(3), 2018, 103110. https://doi.org/10.1080/25765299.2018.1514142

Rugayah, A. F., Astimar, A. A., \& Norzita, N. (2014). Preparation and characterization of activated carbon from palm kernel shell by physical activation with steam. Journal of Oil Palm Research, 26(3), 251-264.

Sani, Y. M., Raji, A. O., Alaba, P. A., Aziz, A. R. A., \& Daud, W. M. A. W. (2015). Palm frond and spikelet as environmentally benign alternative solid acid catalysts for biodiesel production. BioResources, 10(2), 3393-3408. https://doi.org/10.15376/biores.10.2.3393-3408

Shafie, S. M., Mahlia, T. M. I., Masjuki, H. H., \& Ahmad-Yazid, A. (2012). A review on electricity generation based on biomass residue in Malaysia. Renewable and Sustainable Energy Reviews, 16(8), 5879-5889. https://doi.org/10.1016/j.rser.2012.06.031

Sayğılı, H., \& Güzel, F. (2018). Novel and sustainable precursor for high-quality activated carbon preparation by conventional pyrolysis: Optimization of produce conditions and feasibility in adsorption studies. Advanced Powder Technology 29(3), 726-736. https://doi.org/10.1016/j.apt.2017.12.014.

Tang, C., Shu, Y., Zhang, R., Li, X., Song, J., Li, B., Zhang, Y., \& Ou, D. (2017). Comparison of the removal and adsorption mechanisms of cadmium and lead from aqueous solution by activated carbons prepared from Typha Angustifolia and Salix Matsudana. RSC Advances, 7(26), 16092-16103. https://doi.org/10.1039/ C6RA28035H

Wang, L., \& Jian, L. (2013). Removal of methylene blue from aqueous solution by adsorption onto crofton weed stalk. BioResources 8(2), 2521-2536.

Wang, Z., Shirley, M. D., Meikle, S. T., Whitby, R. L. D., \& Mikhalovsky, S. V. (2009). The surface acidity of acid oxidised multi-walled carbon nanotubes and the influence of in-situ generated fulvic acids on their stability in aqueous dispersions. Carbon 47(1), 73-79. https://doi.org/10.1016/j.carbon.2008.09.038 
Xu, M., Li, D., Yan, Y., Guo, T., Pang, H., \& Xue, H. (2017). Porous high specific surface area-activated carbon with co-doping N, S and P for high-performance supercapacitors. RSC Advances 7(69), 43780-43788. https://doi.org/10.1039/C7RA07945A

Yeung, P. T., Chung, P. Y., Tsang, H. C., Tang, J. C. O., Cheng, G. Y. M., Gambari, R., Chui, C. H., \& Lam, K. H. (2014). Preparation and characterization of bio-safe activated charcoal derived from coffee waste residue and its application for removal of lead and copper ions. RSC Advances, 4(73), 38839-38847. https://doi.org/10.1039/C4RA05082G

Zaini, M. A. A., Okayama, R., \& Machida, M. (2009). Adsorption of aqueous metal ions on cattle-manurecompost based activated carbons. Journal of Hazardous Materials, 170(2-3), 1119-1124. https://doi. org/10.1016/j.jhazmat.2009.05.090

Zuo, X. (2014). Preparation and evaluation of novel thiourea / chitosan composite beads for copper(II) removal in aqueous solutions. Industrial and Engineering Chemistry Research, 53(3), 1249-1255. https://doi. org/10.1021/ie4036059 